\title{
Technological and Societal Changes and Their Impacts on Resource Production and Use
}

\author{
Arnulf Grubler \\ Acting Program Director, Transitions to New Technologies, International Institute for Applied Systems Analysis, \\ Laxenburg, Austria
}

Received February 7, 2020; accepted February 8, 2020; published online February 13, 2020

\begin{abstract}
The traditional narrative of continued economic growth driven by development aspirations towards material-intensive lifestyles and associated ever larger extraction and use of resources is contrasted with an alternative perspective. This alternative may lead to much lower growth, even to a "de-growth" of biogenic, energetic, and mineral resources. Disruptive innovations, above all digitalization, combined with changing consumer preferences and lifestyles as well as public policies to address climate change could challenge traditional business models and forms of service provision. Examples of such disruptive innovations in the domains of digital convergence and the sharing economy are given with their potential implications on resource use. Two contrasting scenarios, quantified to 2050 , illustrate the wide divergence of potential developments in resource extraction and use over the coming decades.
\end{abstract}

Keywords: History and scenarios of material use, Disruptive innovations, Digitalization, Sharing economy

Technologischer und sozialer Wandel und seine Auswirkungen auf Ressourcenverbrauch

Zusammenfassung: Das traditionelle Narrativ fortwährenden Wirtschaftswachstums, das durch wirtschaftliche und soziale Entwicklung und damit einhergehende Materialintensive Lebensstile - die zu immer größerem Mehrverbrauch von Ressourcen führen - bewirkt wird, wird mit einer alternativen Sichtweise kontrastiert. Diese alternative Sichtweise könnte auch zu einem viel geringerem Wachstum des Rohstoffverbrauchs, ja sogar zu einem Schrumpfen der Nachfrage nach Biomasse, Energie und mineralischen Rohstoffen führen. Disruptive Innovationen,

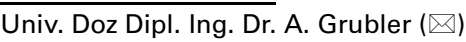

Acting Program Director, Transitions to New Technologies,

International Institute for Applied Systems Analysis,

Schlossplatz 1,

2361 Laxenburg, Austria

gruebler@iiasa.ac.at vor allem Digitalisierung, veränderte Wertvorstellungen und Lebensstile und auch Klimapolitik könnten traditionelle Absatzmodelle und Formen der Dienstleistungsbereitstellung herausfordern. Beispiele disruptiver Innovationen in den Gebieten der digitalen Konvergenz und der Ökonomie des Teilens und ihre potenziellen Auswirkungen auf Ressourcenverbrauch werden aufgezeigt. Zwei kontrastierende Szenarien, die bis 2050 quantifiziert werden, zeigen die weite mögliche Divergenz zukünftiger Entwicklungen in Abbau und Verwendung von Rohstoffen auf.

Schlüsselwörter: Vergangenheit und Zukunftsszenarien des Rohstoffverbrauchs, Disruptive Innovationen, Digitalisierung, Ökonomie des Teilens

\section{Introduction}

The history of materials use since the onset of the Industrial Revolution is characterized by continued and spectacular growth, albeit with changing underlying drivers and rates of change [1]. Throughout much of the 19th Century, growth in materials extraction, processing and use was fuelled by industrialization and infrastructure build-up of an ever growing number of industrializing nations in the Global North. Growth in the 20th Century was driven by an emerging mass-consumption society, suburbanization and pervasive diffusion of private transport vehicles (automobiles) and associated infrastructures in the Global North as well as industrialization and economic "catch-up" in the Global South. In the mature economies of the Global North materials use is largely saturated, i.e. materials use decouples increasingly from economic growth: These economies "dematerialize" [2], even if only in relative terms, leading to a stabilization of materials use at a high level and with materials production partly relocating to the Global South. In the emerging economies of the Global South, population and economic growth as well as industrialization continue to be fundamental drivers of expanding materials use and production, compounded by the effects of globalization and 


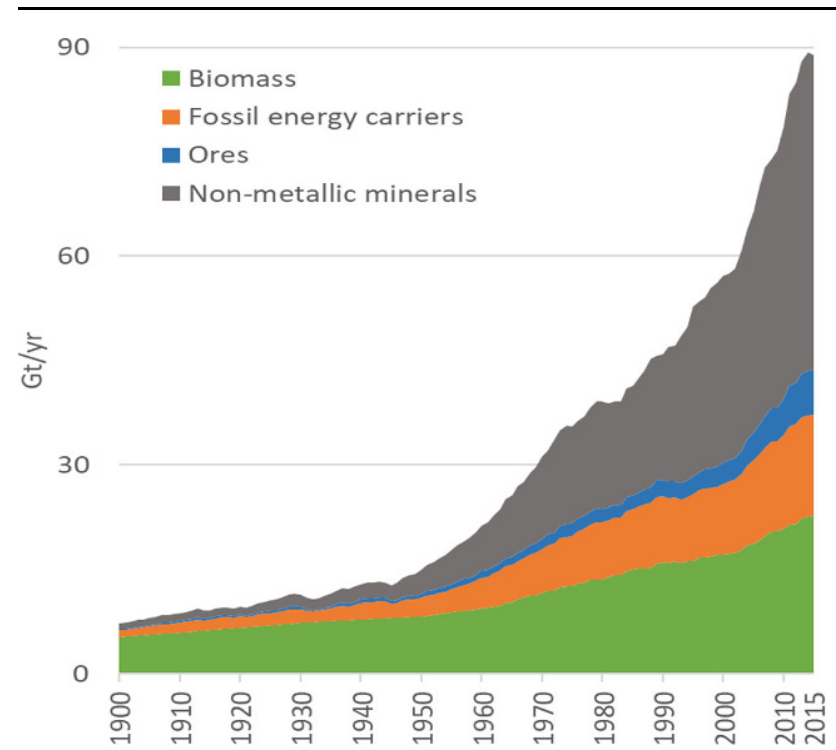

Fig. 1: Global Materials extraction and use 1900-2015, in Gt(Billion tons). Data source: [3]

relocation of resource extraction and processing from the Global North to the Global South, particularly in Asia.

The combined impacts of above diverse development trends resulted in a spectacular expansion of materials use and production throughout the 20th Century ([3] and Fig. 1). Aggregated over biomass (food, feed, and materials), (fossil) energy, ores (metals) and non-metallic minerals (primarily construction materials), global material use increased from some $7 \mathrm{Gt}$ in 1900 to $90 \mathrm{Gt}$ by 2015 , i.e. more than 10 -fold; or from less than 5 tons per capita in 1900 to over 12 tons per capita by 2015 [3]. Evidently these global averages mask enormous disparities in levels of material use between rich and the poor, between countries (North-South), but also between different segments of the population (within countries of the Global South), disparities that are often interpreted as fundamental drivers of future growth in materials use.

By and large, the historical developments provide a powerful support of the up to now dominant narrative of the materials sector: Growth is fuelled by the combination of population and economic growth and the globalization of materials-intensive lifestyles and associated artefacts and infrastructures (high calorie meat-intensive diets, single family homes, automobiles, consumer goods, roads, shopping malls, etc.) that is likely to continue with the development aspirations in the Global South and a perceived globalization of "Western" lifestyles, all of which provide for continued growth of materials use (and extraction) for decades to come: "business as usual" or rather "development as usual".

An alternative development narrative is, however, slowly emerging. Some point to the high inefficiencies and vast environmental impacts associated with "development as usual" and to the vast potentials for improved efficiency in resource use [4] without compromising amenities and services provided. Others [5] highlight the imperatives of sustainable development and the respect for (environmental) "planetary boundaries" [6] that have recently been enshrined in the 17 Sustainable Development Goals (SDGs) of the United Nations, embraced by all nations on the planet. A new literature on "disruptive innovations" [7] accumulates increasing evidence on new emerging trends of social and technological change that could disrupt the traditional "development as usual" paradigm. Examples of such disruptive innovations are illustrated in the following sections.

\section{New Trends in Social and Technological Change}

Social and technological changes-intertwined and co-dependent-have always fundamentally shaped human development. Many of them are incremental and gradual and happen all the time. A few however, represent radical changes that occur infrequently-but clustered-and change dominant development paradigms into new directions. Joseph A. Schumpeter [8] referred to them as "radical" innovations. More recently Clayton M. Christensen [9] speaks of "disruptive" innovations, defined as those that hold potential to change traditional business models, forms of market organization, models of service provision, products, etc.

The advent of pervasive digitalization as enabling "general purpose technology" provides a perfect example of such disruptive innovations. The largest transformative impacts of digitalization on materials consumption and production arise from two trends [10]:

(Near) zero marginal costs of digital transactions, i.e. an additional unit of consumption (e.g. a video or music streaming/download) can be provided at practically zero costs, which can vastly reduce costs and hence increases affordability for poorer segments of society. Hence, the interest of substituting current dominant, resource intensive, physical products and services by digital, "virtual" services as main element of a "dematerialization" strategy.

The possibility of matching supply and demand in realtime through digital coordination platforms offer vast potentials for better asset utilization and improved quality of service. This is in essence the underlying principle of the socalled "sharing economy" in which the traditional model of service provision is shifted from "ownership" to "usership" of devices providing consumer services. "Just in time" service provision models can also make traditional differentiations for instance as between public (large volume, low costs, schedule based, fixed access and delivery stations) and private (low volume, high cost, flexible timing and delivery points) transport increasingly blurred if not obsolete.

Fig. 2 provides (a non-exhaustive) list of recently proposed or introduced digitally enabled new service provision models [11]. The multitude of different innovations can be summarized conveniently under three generic principles:

a. the move from service provision models that rely on ownership (of end-use devices like cars, TV sets, etc.) to "usership" (i.e. use of rented devices or use of digital rather than analog, physical services); 
Fig. 2: Examples of disruptive end-use innovations enables by digitalization. Source: [11]

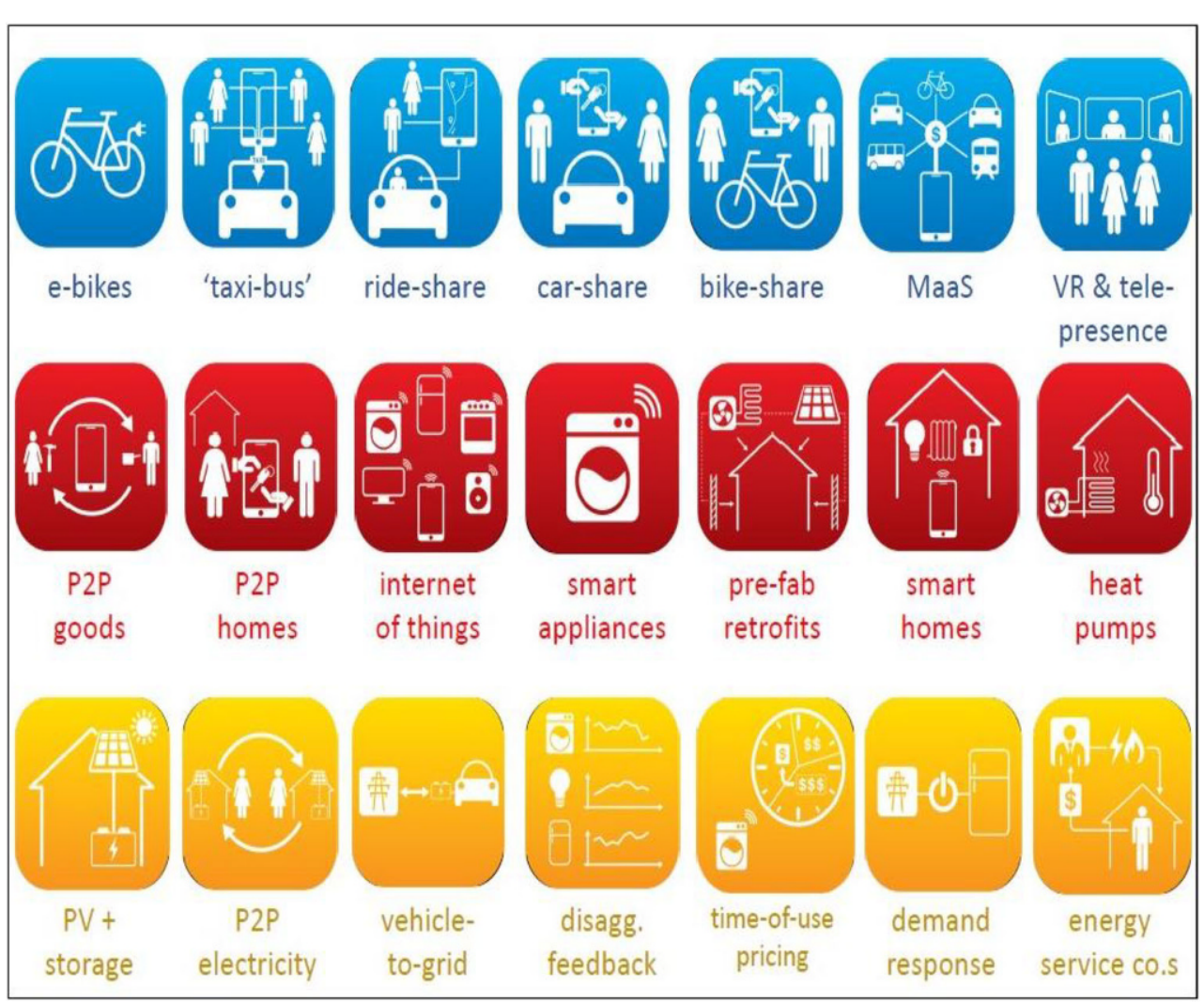

b. the reorganization of traditional segmented "top-down" (producer to consumer) market transactions to a "sharing economy" of "pro-sumers" (consumers becoming also producers of services instead of remaining passive consumers);

c. the move from "atomized" services towards integrated and connected systems (digital convergence, Internet of Things, etc.).

Observed technological and social changes underpin and support above transformations. For instance the rapid diffusion of mobile phones to currently over 8 billion devices worldwide (more than the global population), have resulted in almost equal access to this communication technology. Mobile phones are now the technology that is most equitably distributed across all consumers on the planet, even more equitably than TVs or radios [12]. About half of mobile phones already are smartphones, which are also becoming increasingly adopted by older generations as well beyond their almost universal adoption among the young.

The traditional appeal of owning end-use devices is also eroding. Perhaps the most significant trend is the declining percentage of people that hold driver's licenses that is declining across all age cohorts across all major OECD countries [13] with declines more pronounced among the age group below 25 years. The most extreme example is provided by the city of Stockholm Sweden, where only $10 \%$ of the population below 21 now hold a driver's license [14].

\section{Examples of Disruptive Innovations and Their Impacts on Resource Use}

Fig. 3 illustrates the principles of digital service provision and of device convergence and its resulting materials and resource impacts. The traditional mode of a multitude of atomized services being provided by consumer-owned separate, analog end-use devices is replaced by an integrated digital service platform (the smartphone) that delivers all digital services (communication, entertainment, financial transactions, shopping, etc.) via a single device.

Assuming $100 \%$ replacement, this results in a reduction of materials use (weight) by a factor of 260 (from 26 to $0.1 \mathrm{~kg}$ ) corresponding reductions in embodied energy of a factor of 23, operational energy of a factor of 26 and peak power use (critical for load management) by a factor of 90 (from some 450 to $5 \mathrm{~W}$ ) [15]. The impacts of digital services and device convergence are thus indeed disruptive for a range of industries including consumer electronics, media production, as well as manufacturing and materials processing and extractive industries.

Another example of disruptive change is provided by novel integrated shared mobility models for providing urban transportation needs. Through a series of detailed simulations the OECD International Transport Forum (ITF) has examined several cities for their potential to dislodge the traditional market segmentation between private and public transport via an integrated shared mobility platform [14]. There private vehicles and most of public buses are replaced by a fleet of shared taxis (6-seaters), mini-buses (8- 

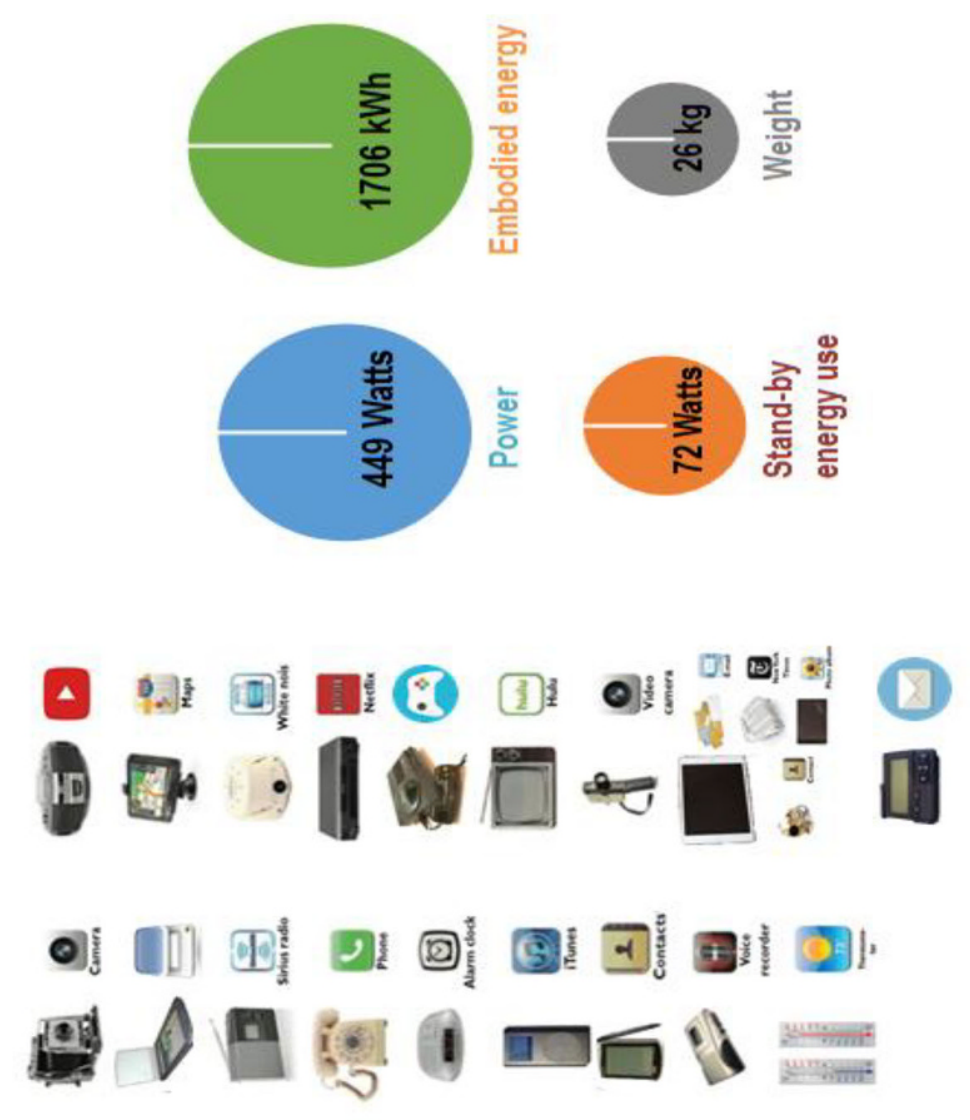

II

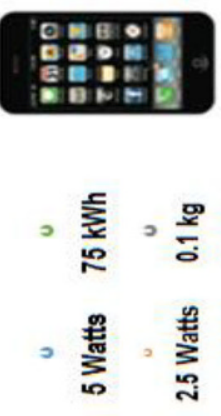

seaters) and midi-buses (with 16 seats) that provide feeder services to the "backbone" high capacity public transport systems like metro, tram, or rail services, that remain largely unchanged (only with capacity expansion). This fleet of shared mobility vehicles is coordinated by a "just in time" mobility scheme coordinated via a central dispatching system which passengers use via a smartphone app with pickups in real-time from their home (shared taxis) or from shared-mobility nodes located at a maximum distance of 400 meters from any home (taxi-buses require $30 \mathrm{~min}$ advance booking via the shared mobility app). Detailed, spatially-explicit simulations with an Agent-based Model (ABM) map in real-time the mobility patterns (origin-destination trips) of the entire population of a city over a day with a matching shared mobility urban transport fleet and calculate vehicle stock requirements, transport speeds, costs, congestion and energy use and emissions. (Fig. 4).

The integrated shared mobility system provides stepchange improvements on all indicators of urban transport performance. Compared to the status quo, the entire mobility of a city at any desired time and destination can be provided with only $2-5 \%$ of the original vehicle fleet, reducing congestion by $30-50 \%$, and reducing costs and $\mathrm{CO}_{2}$ emissions by half. For materials, the drastically reduced vehicle fleet translates into significant reductions in material requirements for the manufacturing of vehicles, moderated only by their much higher utilization rate and higher transport distances and hence shorter lifetime. In turn the 
Fig. 4: Urban shared mobility case studies and their impacts. Source: based on [14]

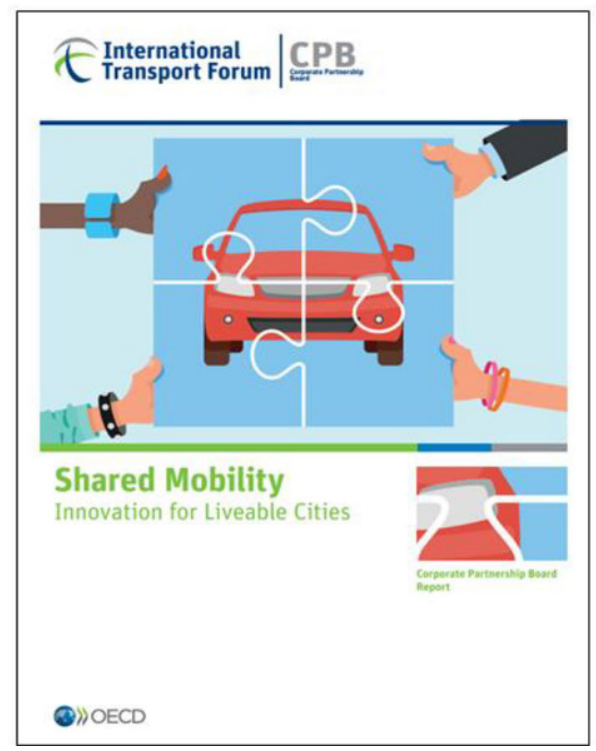

Reductions (\%) in shared mobility scenario compared to status quo

$\begin{array}{lrrrr} & \begin{array}{r}\text { vehicle } \\ \text { fleet }\end{array} & \begin{array}{c}\text { con- mobility } \\ \text { gestion }\end{array} & \begin{array}{r}\text { CO2 } \\ \text { costs emissions }\end{array} \\ \text { Auckland } & -95 \% & -49 \% & -43 \% & -54 \% \\ \text { Dublin } & -98 \% & -43 \% & -50 \% & >-31 \% * \\ \text { Helsinki } & -96 \% & -37 \% & -43 \% & >-34 \% * \\ \text { Lisbon } & -97 \% & -30 \% & -50 \% & -62 \%\end{array}$

* IC vehicle fleets, no electrification

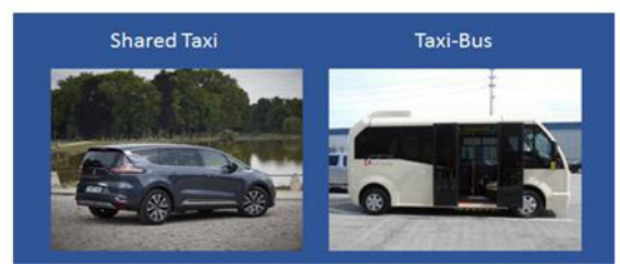

resulting faster turnover rate of the shared mobility fleet allows for rapid innovation and introduction of alternative propulsion systems (electric, or fuel cells) within less than 10 years [15].

Illustrative quantifications suggest a minimum reduction potential e.g. for steel use for vehicles of at least 100 Mio. tons/year by 2050 [15].

\section{Scenarios of Materials Use to 2050}

Fig. 5 illustrates the potential convergence in global materials use contrasting history with two scenarios to 2050 . The Global Convergence scenario [3] basically describes a "development as usual" pathway in which global materials use more than doubles by 2050 (215Gt) compared to the present (2020: 100 Gt). Growth in materials use in such a scenario characterizes all categories from biomass (food, feed, fiber) $+40 \%$, fossil fuels $+70 \%$, and minerals (metals) and non-metallic minerals (construction materials) which nearly triple each.

Conversely, in the Low Energy Demand (LED) scenario [15] in which above discussed disruptive social and technological innovations unfold progressively, illustrating a pathway to SDG12 (Sustainable Development Goal 12, responsible consumption and production) global materials use stabilizes, even declines slightly by 2050 to some $83 \mathrm{Gt}$. Growth is very uneven in such a scenario rang-
Fig. 5: Global materials extraction and use 1900-2015 and for two scenarios to 2050, in Gt (Billion tons). Source: based on [3] and [15]

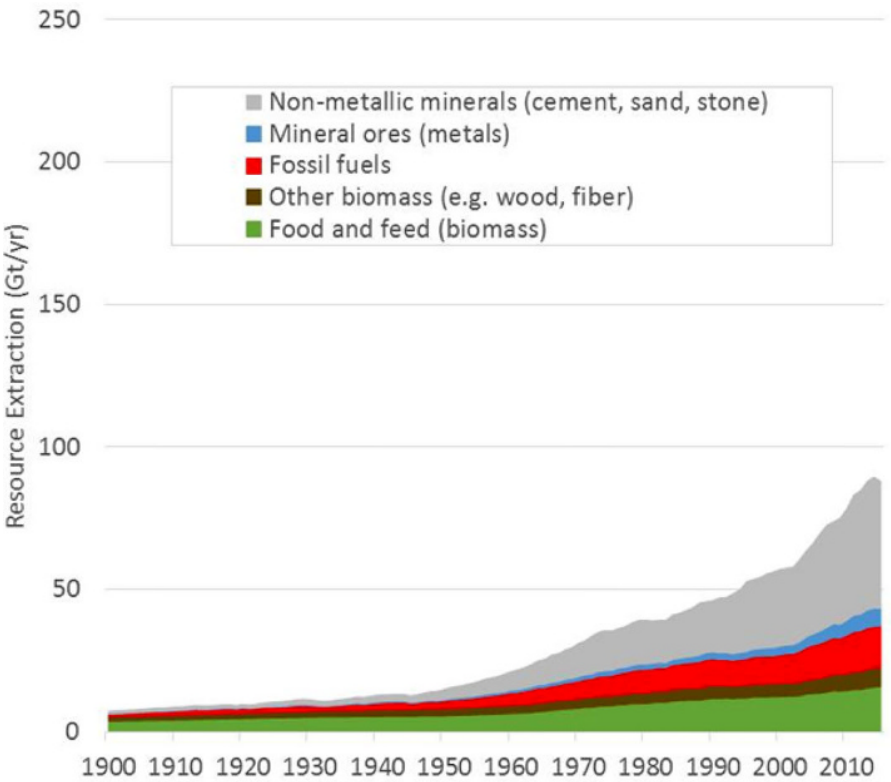

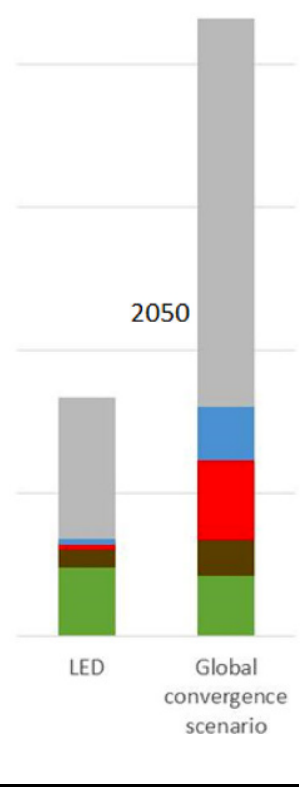


ing from expansion (biomass $+33 \%$ ), stabilization/slight decline (non-metallic minerals $-6 \%$ ) to drastic reductions (minerals $-70 \%$ ) and phase out (fossil fuels -90\%).

The two contrasting scenarios bracket the market development uncertainties for the materials (extraction, processing) and manufacturing sectors for the coming decades. Material categories essential for providing for basic goods and services are less affected by potential impacts of disruptive innovations associated with digitalization (biomass for food, non-metal minerals for shelter and infrastructure) and have quite stable prospects and robust patterns across bifurcating scenarios. Conversely, minerals and above all fossil fuels face a crossroads between boom and bust, depending on whether current technological and social trends continue to prevail, or change radically under the twin influences of disruptive innovations and digitalization, as well as climate policy.

Above presented scenarios should not be interpreted as forecasts or projections. Scenarios are simply illustrations of structured "what if, then" thought experiments, quantified with the help of formal models with the purpose to serve strategic planning for industry and governments. But they illustrate that times indeed seem changing and the future for the materials sector seems to be much wider open now than it was in the past.

Funding. Open access funding provided by International Institute for Applied Systems Analysis (IIASA).

Open Access This article is licensed under a Creative Commons Attribution 4.0 International License, which permits use, sharing, adaptation, distribution and reproduction in any medium or format, as long as you give appropriate credit to the original author(s) and the source, provide a link to the Creative Commons licence, and indicate if changes were made. The images or other third party material in this article are included in the article's Creative Commons licence, unless indicated otherwise in a credit line to the material. If material is not included in the article's Creative Commons licence and your intended use is not permitted by statutory regulation or exceeds the permitted use, you will need to obtain permission directly from the copyright holder. To view a copy of this licence, visit http://creativecommons.org/licenses/by/4.0/.

\section{References}

1. Grubler, A.: Technology and Global Change, Cambridge (UK): Cambridge University Press, 1998

2. Wernick, I.K.; Herman, R.; Govind, S.; Ausubel, J.H.: Materialization and dematerialization: Measures and trends, Daedalus 125 (1996), no. 3, pp 171-198

3. Krausmann, F.; Lauk, C.; Haas, W.; Wiedenhofer, W.: From resource extraction to outflow of wastes and emissions: The socio-economic metabolism of the global economy, 1900-2015, Global Environmental Change 52 (2018), no A1-A2 (September), pp 131-140

4. Lovins, A.B.: Energy Myth Nine-Energy Efficiency Improvements Have Already Reached Their Potential. In: Sovacool, B.K.; Brown, M.A. (eds): Energy and American Society-Thirteen Myths, Berlin: Springer (2007), pp 239-263

5. The World in 2050 (TWI2050): Transformations to Achieve the Sustainable Development Goals, Laxenburg (Austria): International Institute for Applied Systems Analysis, 2018

6. Rockström, J.; W. Steffen, K.; Noone, Å.; Persson, F. S.; Chapin, III, et al.: Planetary Boundaries: Exploring the safe operating space for humanity, Ecology \& Society 14 (2009), no 2, article 32, no pp

7. Wilson, C.: Disruptive low-carbon innovations, Energy Research \& Social Science 37 (2018), March 2017, pp 216-223

8. Schumpeter, J.A.: The analysis of economic change, Review of Economics and Statistics 17 (1935), pp 2-10

9. Christensen, C.M.: The Innovator's Dilemma: When new technologies cause great firms to fail, Boston: Harvard Business School Press, 1997

10. The World in 2050 (TWI2050): The Digital Revolution and Sustainable Development: Opportunities and Challenges, Laxenburg (Austria): International Institute for Applied Systems Analysis, 2019pure.iiasa.ac.at/15913

11. Wilson, C.: Disruptive consumer innovations for transforming energy services, Presentation at the RITE-IIASA Workshop "Rethinking Demand" Nara, Japan, September 2018 https:// www.iiasa.ac.at/web/home/research/researchPrograms/ TransitionstoNewTechnologies/event/5.3_Wilson_Disruptive_ Consumer_Innovations.pdf. Accessed: 2 Febr 2020

12. Zimm, C.: Methodological issues in measuring international inequality in technology ownership and infrastructure service use, Development Studies Research 6 (2019), no 2, pp 92-105

13. Delbosc, A.; Currie, G.: Causes of youth licensing decline: A synthesis of the evidence, Transport Reviews 33 (2013), No 3, pp 271-290

14. International Transport Forum (ITF), Shared Mobility: Innovation for Liveable Cities, Paris, OECD, 2016

15. Grubler, A.; Wilson, C.; Bento, N.; Boza-Kiss, B.; Krey, V., et al.: A low energy demand scenario for meeting the $1.5^{\circ} \mathrm{C}$ target and sustainable development goals without negative emission technologies, Nature Energy 3 (2018), pp. 515-527

Publisher's Note. Springer Nature remains neutral with regard to jurisdictional claims in published maps and institutional affiliations. 